\title{
Phytophthora palmivora CAUSANDO PODRIDÃO DE FRUTOS DE MAMOEIRO NO PARÁ
}

\author{
DINALDO R. TRINDADE \& LUIZ S. POLTRONIERI
}

\begin{abstract}
Embrapa Amazônia Oriental, Cx. Postal 48, CEP 66095-100, Belém, PA, e-mails: dinaldo@cpatu.embrapa.br e poltroni@cpatu.embrapa.br
\end{abstract}

(Aceito para correspondência em 26/02/2002)

Autor para correspondência: Dinaldo Rodrigues Trindade

\begin{abstract}
Phytophthora palmivora, causal agent of fruit rots of papaya in the State of Pará, Brazil

Phytophthora palmivora was isolated from papaya (Carica papaya) fruit rots, from commercial growth in Capanema County, Pará. The fungus was pathogenic to healthy

inoculated fruits and reisolated, fullfiling the Koch postulates. This is the first report of this pathogen on papaya in Pará, Brazil.

O fungo Phytophthora palmivora (E.J.Butler) E.J.Butler tem sido relatado em vários países infetando diversas plantas hospedeiras e no Brasil incluem-se entre as mais importantes, seringueira [Hevea brasiliensis (Willd. ex Adr. de Juss.) Muell \& Arj.], cacaueiro (Theobromae cacao L.), citros (Citrus spp.) e mamoeiro (Carica papaya L.). Em 2001, algumas plantações no município de Capanema, onde se localizam os maiores plantios de mamoeiro no estado do Pará, cultivar Havai, durante a estação chuvosa nos meses de fevereiro, março e abril, observou-se uma forte ocorrência de apodrecimento de frutos na fase final de maturação. Inicialmente os frutos apresentavam exsudação de látex seguindose de lesões cobertas por uma massa esbranquiçada com aspecto cotonoso constituída de micélio do fungo. Procedeuse o isolamento em meio de cultura BDA obtendo-se um isolado apresentando aspecto cotonoso em cultura, micélio cenocítico, esporangióforos e esporangios. Os testes de patogenicidade foram efetuados na cultivar Havai, inoculando-

se os frutos na fase de maturação tendo o isolado se mostrado patogênico. A identificação do patógeno foi baseada em análises morfológicas e morfométricas de esporangióforos e esporângios. Os esporangióforos apresentavam-se simples ou pouco ramificados e os esporangios apresentavam forma oval ou ablonga com papila na parte terminal e um pedicelo curto na base medindo $46 \times 38 \mu \mathrm{m}$ em média, estando dentro dos limites descritos na literatura para P. palmivora (Waterhouse, G.M. Mycological papers,CMI, Kew, 92:1-22, 1963; Ribeiro, 1978; Ho,H.H. Mycologia, 73:705-714, 1981). As características apresentadas pelo isolado e os sintomas reproduzidos pela inoculação, indicam que a podridão dos frutos é causada pelo P.palmivora. Embora seja uma doença que já ocorre em outros estados do Brasil, no estado do Pará trata-se do primeiro relato em frutos de mamoeiro e medidas deverão ser tomadas para evitar que se dissemine para outras regiões do estado que tem no cultivo do mamoeiro uma das principais atividades agrícolas.
\end{abstract}

